\title{
TAPESTRIES OF HOPE: \\ Film, youths and HIV/AIDS in Zimbabwe and South Africa
}

URTHER RWAFA AND LESIBANA RAFAPA

\begin{abstract}
ABTRACT
In Zimbabwe, the marauding effects of the human immunodeficiency virus and acquired immunodeficiency syndrome (HIV/AIDS) are felt in almost all families, among different age groups, class lines, races and creed. The effects are debated and discussed, and different intervention measures are suggested using various forms of media. The communication-science-based interventions and advocacy promoted through film are an integral part of biomedically based scientific research into understanding the nature and manifestations of HIV/AIDS. However, it is worrisome that in most of the research, debates and discussions that focus on HIV /AIDS, adults take the centre-stage. This practice of speaking for youths, and not to and with them, denies the reality that youths are agents of social change whose "voice" and action can have the capacity to transform society for the better in the face of HIV /AIDS. In Zimbabwe, one methodological approach that youths can use to debate and spread the message about the devastating effects of HIV/AIDS is film. In the Zimbabwean section, this article singles out the short film The sharing day (2009) as an informative and communicative tool that features youths dramatising narratives of hope, pain and sorrow as they are confronted by the reality of HIV/AIDS. In the South African section of the article, the abcnews.com documentary (2001) on Xolani Nkosi Johnson's struggle with HIV/AIDS is used to signal hope. The article critiques documentary filmmaking on Johnson, using criteria such as youth involvement (Harrison et al. 2010; Wang 2006), effectiveness of the message (Hanan 2009) and bonding and bridging social capital (Foulis et al. 2007).
\end{abstract}

Keywords: HIV and AIDS, youths, film, Zimbabwe, The sharing day, tapestries of hope, South Africa

\section{Introduction: Film and the methodological challenges of representing HIV/AIDS among the youths}

In this introduction, we want to talk about the methodological challenges of representing the human immunodeficiency virus and acquired immunodeficiency syndrome (HIV/AIDS) through film images. In the early years of the HIV/AIDS pandemic, 
the major thrust was to define and explain the methodological priorities between prevention and treatment of the disease. Today, the discussions, debates and visual representations of HIV/AIDS have become nuanced. More holistic approaches have developed, recognising the need to deal with prevention, care and support (Morris 2003; Zalduondo 2001). Apart from relying on different forms of media, such as radio, television, newspapers and film to spread valuable information concerning the prevention of HIV/AIDS and the care and support that should be given to youths with HIV/AIDS, film images have increasingly become purveyors of valuable information about the disease and the politics underlying its representation.

The ability of film to synthesise verbal and audio-visual elements of communication makes it possible for the medium to create multiple narratives and different perspectives of exploring the challenges brought about by HIV/AIDS. When Zimbabwean and South African youths struggle to create their own "spaces", and cultivate their "voices" through film images, they are taking a "position" that promotes youth visibility and agency in asserting life in the presence of death, a feature noted by anthropologists working in war zones (Rugalema 2004). In most Zimbabwean films that feature youths as the drivers of action, the images tell stories of pain, sorrow and hope in which youths are depicted as initiators of community-based development programmes that focus on combating HIV/AIDS. Youth agency generates habit, imagination and judgment through an interactive response to the challenges presented by HIV/AIDS. The words "interactive response" connote mutuality, that is, the existence of a twoway communication system in which youths can play a pivotal role in exchanging information about the challenges presented by the disease. The result is a positive youth development methodology that film can use to engage youths in critical thinking and action that prepares young people to meet 'the challenges of adolescence and adulthood through a coordinated, progressive series of activities and experiences which help them to become socially, morally, emotionally, physically and cognitively competent' (Peterv 2008, 28).

Positive youth development addresses the broader needs of youths, in contrast to "deficit-based models" (Peteru 2008, 28), which focus solely on youth problems. In other words, Zimbabwean films about youths can be deployed to project a positivist approach that affirms the power of youths to change the situation for the better, and acknowledge that youth identities in the face of HIV/AIDS are a "work in progress" subject to constant and often un/conscious re/negotiation with changing encounters with other ways of seeing, doing and being. Communication development engendered through film promotes new ways of perceiving social relationships in this milieu of HIV/ AIDS. However, Grossberg, Nelson andTreichler $(1992,1)$ are quite aware of the cultural politics of representing HIV/AIDS when they assert that: 
the question of AIDS is also 'an extremely important terrain of struggle and contestation' in which the realities, now and in the future, sexual politics, desire and pleasure, who lives and dies, are bound up in metaphor and representation. What cultural studies must do, and has [sic] the capacity to do, is to articulate insights the constitutive and political nature of representation itself, about its complexities, about the effects of language, about textuality as a site of life and death.

HIV/AIDS does not easily manifest physically on the bodies of those who carry it, not until its last phase when HIV becomes AIDS. Interpreting the symptoms of HIV/AIDS is a contested terrain over the creation and ownership of meaning, and attribution of identities. Since HIV/AIDS symptoms are not always obvious, it is a challenge for film directors to handle the theme with utmost care lest film images are actually used to send wrong signals about the nature and manifestation of the disease. The politics of film representation of HIV/AIDS reveal its ambiguities and underpinning social contradictions. Vambe $(2003,473)$ locates the magnitude of the problem of HIV/AIDS in

cultural identities embedded in notions of African sexuality. The latter is shaped by cultural beliefs, values and notions of "maleness", and "femaleness", "manhood" and "womanhood", especially as determined within a colonial [and post colonial] system that "invents" ideas of African customary law.

African customary laws and traditions can consciously create and "normalise" negative images of teenage girls who fall victim to HIV/AIDS, by describing them as "loose" and thereby deserving of the full wrath of the ancestors. Contrary to this type of imaging, when teenage boys lead promiscuous lives, they can actually receive accolades for proving their "manliness". If Zimbabwean and South African film directors fail to go beyond gender discrimination supported by 'essentialised' and 'exceptionalised' traditional and cultural values, then their credibility is dented. Communication development advocated through "positivist"' film images opposes obscurantist cultural values and practices that prevent, block or censor youths from airing their views in the process of understanding the dynamics of HIV/AIDS. However, despite the existence of development models that encourage positive depiction of youths in the face of HIV/AIDS, the emergence of "phobic visuals" presents a lot of challenges to the filmic representation of youths infected with HIV.

\section{Youths and HIV/AIDS and the birth of "phobic visuals"}

An epistemological understanding of how "phobic visuals" have made in-roads into the film industry calls attention to the following questions posited by Campbell (2008): (1) To what extent do visual images of HIV/ AIDS replicate the idea of the essentialised vector (such as a prostitute) or the stigmatised patient? and (2) How can visual images 
represent in context the dynamic, culturally nuanced, and historically specific sexual networks that contribute to the HIV/AIDS pandemic? These questions are critical because they can lead to an understanding of the internal tapestry of "phobic visuals". There is growing concern that in some contemporary visual images depicting youths with HIV/AIDS, the tendency is to focus on the horrific and traumatic thereby mapping HIV/AIDS in extremis. The net effect of such representations creates 'phobic visuals' that promote fear and a condition of hopelessness in the youths. In other words, individuals are 'sentenced to the black-and-white testimonial space of AIDS victim' (Whatney 1990, 182-183). "Phobic visuals" promote a stigmatised condition of "victimage"'. Thus, once people living with HIV/AIDS are stigmatised, it means that a dark shadow is cast over whatever they do or say.

On a grand scale, the internationalisation of "phobic visuals" has not done any good to improve the image of Africa against the backdrop of HIV/AIDS. In fact, through the sub-title Don't touch! Africa is a virus, Mayer $(2002,258)$ subtly captures the deleterious effects of "phobic visuals" where Africa is depicted as "a noxious influence, a dark 'viral' force at the borderlines of Western civilisation'. Mayer $(2002,290)$ goes further to assert that,

the virus embodies the key qualities of the global age, yet under markedly negative insignia. It discloses the flip side of global contact scenarios, giving vent to the fearful insight that the bright new world of compatibility, cosmopolitanism, and communication is only to be realized at the cost of systemic instability and vulnerability.

Thus, global contact with Africa is viewed as risky because through violent imagery the continent is depicted as the crucible of viral diseases, rather than the crucible of mankind. In the same breath, the viral colonisation of the African body is 'hyped' and energised through violent film images that show the rapid and obnoxious deterioration of diseased black bodies. In this context, African youths are not spared. Through most films about Africa, particularly those that come out of the Hollywood stable, African youths that are infected with HIV/AIDS are portrayed as hopeless beings. The reader is reminded of ghoulish and legendary images of impoverished and infected youths and children from Somalia and Ethiopia with protruding ribs that can be counted one by one. In the same forte, in Zimbabwe the donor funded films such as Everyone's child (1996) and Musinsimuke (2001) talk about the challenges that confront youths growing up in this world dominated by HIV/AIDS. The films are also implicated in spreading 'phobic visuals' by depicting youths as desperate victims that cannot come up with alternative ways of preventing HIV/AIDS. Young men and women are 'hyper-sexed' and depicted as careless in their love relationships, thereby making them appear as if they are cannon 'fodder' for HIV/AIDS. However, a spirit of shared responsibility among the youths exhibited through the film The sharing day (2009) is a redeeming feature that 
can give testimony to the reality that youths can be agents of social transformation in the face of HIV/AIDS in Zimbabwe and South Africa.

\section{Youths HIV/AIDS and the narratives of hope: The case of the sharing day}

The sharing day (2009) is a 50-minute Zimbabwean short film directed by Tsitsi Dangarembga. This short film narrates the 'trials and tribulations' faced by its girl protagonist - Tabeth - who is infected with HIV/AIDS virus. Tabeth is doing grade seven at a rural primary school. She stays with her mother's younger sister because her mother has just died of HIV/AIDS. Tabeth is constantly reminded by her aunt that she is the 'infected one', and her insinuations are clear when she says: 'What are you looking at? Yes, your mother told me that you are not supposed to eat something sweet.' Actually, what is interesting here is that the sweet potatoes that Tabeth is asking for are not for her consumption but are meant for a 'sharing day' that her teacher has arranged at school. Tabeth is stigmatised as a 'victim' who is forbidden to lead a normal life and enjoy the same benefits as other youths of her age. The very act of deciding for Tabeth, and when she thinks otherwise, undermines a positive youth development methodological approach (Peteru 2008) that focuses on the broader needs of youths. Furthermore, the act can reflect the subterranean workings of 'deficitbased models' which focus solely on youth problems. In other words, deficit-based models are 'deficit' in that they empower adults to speak for and to youths in a way that assumes that youths do not possess their own 'voice' and will power to transform their social conditions in the face of HIV/AIDS. Here, the implication is that her guardian should have consulted with Tabeth to find out why she needed sweet potatoes when in fact she was medically advised not take in food that is sweet. Actually, when the school teacher arranged for the pupils to bring different food items for the "sharing day' his intention was to promote a spirit of togetherness among the youths.

In spite of the hard-heartedness demonstrated by her aunt at home, at school Tabeth is exposed to a very different environment. The school environment is one full of activity with young and energetic girls playing all sorts of games, among them Tabeth. The "interactive response" that is created through game playing connotes mutuality; the existence of a vibrant communication system in which youths are involved in problem solving situations. Game playing gives Tabeth lots of hope, because she is part of problem solving situations, and ultimately her lived reality of being the "infected one" is suspended. It is advisable that people living with HIV/AIDS should do some exercises recommended by a physiotherapist. Generally, leading a healthy life creates physically and psychologically stable conditions in which infected people can live positively with the disease. 


\section{HIV/AIDS and good health practices}

In the film narrative, viewers are exposed to Tabeth who is complaining bitterly about the type of food that her aunt is giving her. The food is not doing her health any good because it is causing her diarrhoea. Tabeth makes it clear when she says, "but my mother used to give me good food". Unfortunately, her demands are not taken lightly by her mother's younger sister who shouted at her: "Do you think I'm your mother? Is it not your mother who infected you with HIV?" At this point, viewers are made aware of the reality that Tabeth contracted HIV through mother-to-child transmission. But the "blame-game" that the mother's sister is playing is reflective of her powerlessness in confronting the reality of HIV/AIDS. What she could have done is sought advice and assistance from other members of the community. Through the characterisation of Tabeth and her aunt, viewers are also exposed to a range of standard epidemiological factors that affect people living with HIV/AIDS, such as malnutrition, gender relations, poverty and the lack of public health care in Zimbabwe (Stillwaggon 2003). Actually, most people who die of HIV/AIDS in Zimbabwe - youths included - are the poor who cannot afford expensive anti-retroviral (ARV) drugs and the necessary nutritious foods that go with the drugs. The administering of ARVs is now a health priority. In fact, as Tufte $(2005,107)$ points out, "The current high emphasis on rolling out anti-retroviral treatment is changing the emphasis from focus on prevention or integrated approaches to almost complete focus on HIV treatment'.' This can perhaps help to give victims hope as well as challenge some negative perceptions of HIV/AIDS proffered by some youths who write that, "if you get the HIV virus, your future gets stuck! You become part of real "no future' generation" (Tufte 2005, 107). However, in the film narrative, tapestries of hope are created: (1) when Tabeth is introduced to the ARV by the doctor; (2) when her immunity system is constantly boosted by the local moringa herb that has been used for centuries by the Tonga people of the Zambezi valley to boost their immunity systems; and (3) when the community decided to supply Tabeth with health nutritious food. But in cases where off-screen realities of some youths point to the lived experiences of stigmatisation, alienation and condemnation, HIV/AIDS becomes the politics of who dies or who survives. To it put it differently: HIV/AIDS becomes a terrain of struggle and contestation (Grosberg et al. 1992) in which infected youths such as Tabeth can find themselves at the receiving end. Luckily for Tabeth, her community and school have mobilised enough support to ensure that the family has adequate supplies of food.

\section{HIV/AIDS: Community-shared responsibility}

The sharing day shows how "grass-roots mobilization" theory can be put to practical use through community participation in trying to ameliorate the effects of HIV/AIDS on Tabeth. At this stage, community youths play a fundamental role as care-givers who take turns to give material and moral support to Tabeth. What these youths reflect is that the "energetic, optimistic and invincible" generation (Tufte 2005, 106) born and 
bred inside the thick of the struggle against HIV/AIDS have come to accept the reality of the disease and its marauding effects on the human physiognomy. However, instead of either folding their arms and not doing anything or raising their hands in surrender, the youths have taken it upon themselves to confront the disease by finding alternative ways of supporting Tabeth. This positivist approach towards caring and supporting HIV/AIDS victims is quite redeeming especially when seen against the backdrop of pessimism manifesting itself through the behaviour of the aunt who seems to have lost hope of looking after Tabeth. The aunt is bereft of alternatives; her speech is clear when she asks, "How can I help Tabeth when I have nothing?" The sharing day that the school started exemplifies the existence of community-based initiatives that some societies in Zimbabwe have put in place to combat the epidemiological effects of HIV/ AIDS. The sharing day ends with a clear message that communities in Zimbabwe should share the responsibility of HIV/AIDS other than placing the blame on the victims - living or departed-when they should come out with alternative methods of confronting HIV/ AIDS as a lived reality of the current times.

\section{Youth, HIV and AIDS in South Africa}

The abcnews.com documentary (2001) on Xolani Nkosi Johnson's (hereafter Nkosi) struggle with HIV/AIDS signals hope regarding what writers such as Hanan $(2009,130)$ describe as "making successful communication campaigns for shaping public attitudes related to social stigmas and issues about HIV/AIDS". We critique documentary filmmaking on Nkosi, using criteria such as youth involvement (Harrison et al. 2010; Wang 2006), effectiveness of the message (Hanan 2009), and bonding and bridging social capital (Foulis et al. 2007). The importance of effective HIV/AIDS intervention and communication campaign in South Africa cannot be overemphasised, considering that at the time of Nkosi's personal strife with the disease, according to UNAIDS South African youth aged 15-24 were 'experiencing among the highest HIV prevalence in the word' (Harrison et al. 2010), culminating in "about 6 million people in South Africa . . . living with HIV" today following developments since then (Cullinan 2013, 10).

The documentary opens with a voice-over framing the thoughts of the 12-year-old ailing boy with that of the 2001 soccer world cup held in South Africa. This may be interpreted as a deliberate embedding of the HIV/AIDS message with the animus of hope required within the world cup festive mood, thus off-setting a coupling of the message with sombreness. Rather than scare the audience into acknowledging the severity of HIV/AIDS, the producer opts for a more sound reception of the message in which the audience is urged to appreciate its potential vulnerability through critical engagement with the issues. According to what Uwah and Ebewo $(2013,124)$ describe as the Extended Parallel Process Model of HIV/AIDS information campaigning, fear could otherwise have ensued had the message not been lent a jolly ring, leading to the 
audience counterproductively using " a defensive mechanism to cope with their fear" emanating from "processing a message triggered by high perceived threat and not being convinced of their ability to deter the threat"', out of a paralysing despondency.

According to the health communication Theory of Reasoned Action, "willingness to perform safe health behaviours is determined by the individual's perception of the evaluation of the behaviours by important others" (Uwah and Ebewo 2013, 123). Alongside purposely selected and sequenced images constituting the narrative of the documentary film, the voiceover continues to give the sanguine messages concerning Nkosi's adoptive mother Gail Johnson together with the international non-governmental organisation (NGO) providing her with funding; the AZT drug provider; supporting celebrities with whom the emaciated boy dines on his visit to the United States (US); and Nelson Mandela befriending Nkosi. The documentary producer's inclusion of this information in the narrative promises to succeed in persuading the audience to change to safe health behaviours as a result of decoding the important others as endorsing such safe health behaviours for the prevention of HIV/AIDS. Moreover, the audience cannot but derive a message of hope to conquer HIV/AIDS, from the voiceover's explicit assertion of the "symbols of compassion and kindness" elicited by both the existence and footage of the care centre for HIV positive women and children. The centre is named Nkosi's Haven and uses the face of the boy proclaiming publicly that he was born HIV-positive campaigning for the Mbeki administration to roll out AZT drugs to pregnant people living with Aids (PWAs) and declaring that he wants to 'do a lot for others out there"'. The "'others out there" ' are stigmatised women on the verge of dying of HIV/AIDS the way his mother did, equally stigmatised and dying children, and many more members of the South African populace affected by HIV/AIDS the way Gail Johnson is. These others do not necessarily believe in their own efficacy to intervene and mount campaigns as Gail Johnson did for healthy living through a mobilisation for the bonding and bridging of social capital.

Bonding of social capital entails joining the forces between ordinary grassroots people or groups and authorities relevant for the success of HIV/AIDS information and intervention campaigns, while bridging of social capital means seamless accessing of required resources between role players at the local, political and international levels (Foulis et al. 2007). Apart from Mandela and the bodies he is associated with, the US celebrities and the international NGO mentioned in the documentary voiceover, bridging social capital, significant bonding takes place between the aforementioned sophisticated persons and the admittedly little educated and less known Gail Johnson. Gail Johnson's stature is not made part of the narrative of the 2001 abcnews.com documentary film. It is instead part of the narrative of a documentary filmed a year after Nkosi's death plaintively entitled 'Nkosi Sikelel' iAfrika"' (YouTube 2002). 
The latter documentary of 2002 frames an interview with Smith driving in a car through an impoverished suburb with flitting images of Nkosi alone and with Gail Johnson hugging him; a black woman with a heavy load of alms on her head probably returning home from toiling in a rich suburb; a black man pulling a trolley overloaded with recycling bits and scraps against the backdrop of a squalid black residence' an apparent teenage mother sauntering over a bridge with a baby strapped to her back; and flashback images of some members of the public buying and laying flowers on hearing of Nkosi's death after he had succumbed to HIV/Aids (YouTube). By such a framing the producer 'assumes a structure-centred approach' that addresses structural dynamics such as poverty, cultural taboos, and gender stereotypes, vital for health communication (Uwah and Ebewo 2013, 132). It is only through the structure-centred approach that 'the most important concerns of the health communication scholar of the new millennium' will be addressed, of finding "ways of reaching out to marginalised groups" (Uwah and Ebewo 2013, 133).

In the interview, the voiceover interview with Gail Johnson, Smith states that she does not have a university education and is a plain working class woman who was fuelled into doing something about HIV/AIDS after "a friend of [hers] died of AIDS" (YouTube). It is these facts from the interview that reveal the nature of social capital bridging that has taken place before Nkosi's Haven could exist and Nkosi's story be exposed to the world through television and other media. It is thus a feat for the dynamics within the Nkosi Johnson intervention and information campaigns to have assumed what the voice-over in the 2001 abcnews.com documentary describes as an "African struggle against AIDS". The marginalised, under-resourced section of society excluded from most unsuccessful HIV/AIDS campaigns finds parallels in all of Africa, hence the laudable inclusion of the marginalised sectors in the Nkosi Johnson project being made eponymous for all of Africa.

The abcnews.com documentary (2001) on the Nkosi Johnson HIV/AIDS saga contains images in which the 12-year-old Nkosi is attending a party with other kids and in a classroom with his classmates. In a documentary compiled eight years after Nkosi's death, the voiceover takes the viewers through interviews with Gail Johnson and images of a young boy called Thabiso, whose mother is living with HIV/AIDS among the more than 60 mothers and children accommodated and cared for at Nkosi's Haven. The images are reminiscent of those of Nkosi taking medication in a kitchen of Nkosi's Haven then having a balanced, sumptuous meal. The narratives of both documentaries yield the message that people living with and affected by HIV/AIDS deserve to be treated with respect and love like anyone else. Such a message is sustained in another documentary commemorating Nkosi's 2002 posthumous honour in recognition of his fighting the stigma attached to HIV/AIDS as an aspect of attaining healthy living in spite of living with HIV/AIDS. The alternating and recycling images here are still (probably as a reminder that the documentary is posthumous), portraying Nkosi 
climbing a tree with a beaming face full of hope, feeding on soup with peeling lips and his frail body, lying critical in hospital, posing elegantly on a bed with a teddy bear by his side during much happier and healthier days, and so on.

The emotion such narratives is likely to provoke in the audience consisting of mostly marginalised blacks, women and children is that PWAs, too, deserve commemoration, honour, care and respect and can live their lives to the full. What these documentaries achieve is what Hanan (2009) describes as self-efficacy among the audience exposed to an HIV/AIDS information campaign being crucial for members of the audience in order to feel confident that they can beat the obstacles towards complying with safe health practices championed by the campaign. For young people likely to identify with the images of the documentary due to common age group and economic structure, such a selection of images should evoke agentive enthusiasm to act like Nkosi and the other children and come out about their HIV status in order to be provided with care thereby subsuming the benefit of eroding the stigma associated with HIV/AIDS. It is from a similar structural perspective that a writer such as Wang $(2006,159)$ has declared that: "Youth involvement ... harnesses the desire of young people to exercise autonomy and express creativity ... to build a more healthful and democratic society'.

As part of an HIV/AIDS information and intervention campaign, the Nkosi Johnson documentaries discussed in this part of the article need to undergo "success evaluation" so that the "penetration and persuasion level" of their message can be determined (Hanan 2009, 153). One criterion for investigating this is rigour that goes with "well-designed programmes" defined as "those focused specifically on preventing or reducing HIV related risk behaviours in young people"' (Harrison et al. 2010). The Nkosi Johnson documentaries appear to have contributed to hope regarding the HIV/AIDS situation in South Africa today, where the "new infection rate has fallen by about half in the last decade" despite remaining "the world's highest"' (UNAids in Cullinan 2013, 10).

\section{Conclusion}

The article explored how youths in Zimbabwe are involved in creating possibilities for hope in the face of HIV/AIDS. It has been argued that instead of viewing youths as "passive" recipients of information that should be "spoken" to regarding HIV/AIDS, Zimbabwean youths have revealed that they can be agents of social change. This notion is well supported through "positive development" "models that emphasise youth participatory methodologies in deciding their fate in the face of HIV/AIDS. The idea of "positive development"' is subtly captured through the short film The sharing day in which the female protagonist - Tabeth - survives all odds through youth initiatives that give her hope as well as the will power to live positively with the disease. It was 
also argued that some film images in Zimbabwe and the world over are implicated in creating "phobic visuals" that represent youths as hopeless victims that are always told what do regarding their conditions as the "infected ones". The article has taken a position that supporting youth initiatives exemplified by grade seven pupils who did not despair but continued to give moral and material support to Tabeth and her aunt. The discourses of The sharing day are redeeming because they depict that through collective effort and a "never surrender" attitude, communities can make a difference in the face of HIV/AIDS in Zimbabwe. On the other hand, the Nkosi Johnson documentaries appear to have contributed to raising hope regarding the HIV/AIDS situation in South Africa today, where the "new infection rate has fallen by about half in the last decade" despite remaining "the world's highest" (UNAids in Cullinan $2013,10)$. In short, there is need to take stock of what HIV/AIDS has done to Zimbabwe and South Africa in order to compare strategies that the two countries have used to communicate the pain as well as potential hope of the possibility of stemming the spread of the disease.

\author{
About the authors \\ URTHER RWAFA \\ Department of Film and Theatre Arts \\ Midlands State University [MSU] \\ rwafau@unisa.ac.zw \\ Research Fellow \\ Department of English Studies \\ University of South Africa [UNISA] \\ LESIBANA RAFAPA \\ Department of English Studies \\ University of South Africa \\ rafaplj@unisa.ac.za
}

\title{
Primary sources: Filmography
}

abcnews.com documentary. 2001.

Dangarembga, T. (dir).1996. Everyone's child. Harare: Media for Development Trust.

Dangarembga, T. (dir). 2009. The sharing day. Harare: Media for Development Trust.

Markham, E. (dir). 2001. Musinsimuke. Harare: Media for Development Trust.

\section{References}

Campbell, C., C.A. Foulis, S. Maimane and Z. Sibiya. 2007. The impact of social environments on the effectiveness of youth HIV prevention: a South African case study. AIDS care 17(4): 471-478.

Campbell, D. 2008. The visual economy of HIVIAIDS. A report for the AIDS, security and conflict initiative. http://asci.researchhub.ssrc.org/rdb/asci-hub (accessed 6 July 2013). 
Cullinan, K. 2013. Striking gains made in fight against AIDS, report states. The Star, 24 September, p.10.

Grossberg, L., C. Nelson and P. Treichler, eds. 1992. Cultural studies. London: Routledge.

Hanan, M.A. 2009. HIV/AIDS prevention campaigns: a critical analysis. Canadian Journal of Media Studies 5(1): 129-158.

Harrison, A., M-L. Newell, J. Imrie and G. Hoddinott. 2010. HIV prevention for South African youth: which interventions work? A systematic review of current evidence. BMC Public Health 10(102).

Mayer, R. 2002. Artificial Africas. Colonial images in the times of globalisation. Hanover and London: University College of New England.

Morris, N. 2003. A comparative analysis of diffusion and participatory models in development communications. Communication Theory 13(2): 225-248.

Peteru, P. S. 2008. Youth development: a pacific content. Journal of Commonwealth, Youth and Development 6(1): 23-35.

Rugalema, G. 2004. Understanding the African HIV pandemic: an appraisal of the contexts and lay explanations of HIV/AIDS pandemic with examples from Tanzania and Kenya. In HIV and AIDS in Africa: beyond epidemiology, ed. E. Kalipeni, J.R. Craddock, J.R. Oppong and J. Ghosh, 191-203.Oxford: Blackwell.

Stillwaggon, E. 2003. Racial metaphors: interpreting sex and AIDS in Africa. Development and Change 34(5): 809-823.

Tufte, T. 2005. Communicating for what? How globalization and HIV/AIDS push the ComDev agenda. In Media and global change. Rethinking communication for development, ed. 0 . Hemer and T. Tufte, 105-1 19.Göteborg, Sweden and Buenos Aires, Argentina: NORDICOM.

Uwah, C. and P. Ebewo. 2013. Examining the efficacy of health communication theories in the fight against HIV/AIDS in Southern Africa. In Africa and beyond: arts and sustainable development, ed. P. Ebewo, I. Stevens and M. Sirayi, 123-137. Newcastle upon Tyne: Cambridge Scholars Publishing.

Vambe, M.T. 2003. HIV/AIDS, African sexuality and the problem of representation in Zimbabwean literature. Journal of Contemporary African Studies 21 (3):473-488.

Wang, C. 2006. Youth participation in photovoice as a strategy for community change. Journal of Community Practice 14(1): 147-161.

Whatney, S. 1990. Photography and AIDS. In The critical image: essays on contemporary photography, ed. C. Squires. Seattle: Bay Press.

Zalduondo, B.O. 2001. Second generation HIVIAIDS communication: applying lessons learned. Presentation to USAID, Washington. 